\title{
The Effect of the Global Economic Recession on the South African Labour Market
}

\author{
Motseotsile Clement Marumoagae \\ Lecturer, Faculty of Law, Mafikeng Campus, North-West University \\ Email: clement.marumoagae@nwu.ac.za
}

Doi:10.5901/mjss.2014.v5n23p380

\begin{abstract}
Unlike most other countries in Africa, South Africa has historically been a significant player in international markets. Given this global economic engagement, South Africa felt the effects of the global recession both quickly and deeply when some of the major markets in the world were struck by the economic meltdown in 2008. Major sectors within the South African economy began to retrench employees thus testing the efficiency of the South African retrenchment laws. This paper highlights the impact of recession within the South African labour market and assesses how the government responded to these phenomena.
\end{abstract}

Keywords: Recession, Economy, Retrenchment, Employee, Employer, National Development Plan.

\section{Introduction}

Amongst African countries, South African economy is by far the most integrated into the global economy, thus it was one of the first African countries to be truck by the global financial crisis which originated in the United States of America. This paper evaluates the impact of the 2008 global economic meltdown on the South Africa labour market in the light of challenges facing the state with regard to unemployment. First, I will demonstrate that the international community was confronted by the recurrence of a rare economic phenomenon as the waves of the economic meltdown swept through the entire globe. The economic crisis was ignited in the financial markets of the major developed economies but soon the developing world was affected (Ene, 2011:1). This effectively led to the fall of world stock markets and the collapse of large financial institutions. As a result, governments of developed nations came with rescue packages to bail out their financial systems (Rtholtz and Task, 2009: xiv). It is true that when recession hits a country, the labour market of that country becomes mostly affected. Secondly, I will assess the impact of global economic crisis on the South African labour market, more particularly regarding retrenchments which were experienced in South Africa during the recession. Thirdly, I will reflect on the pre-dismissal procedures relating to operational requirements in South Africa, thus indicate how certain employees were able to use sound South African retrenchment laws against scrupulous employers who sort to take advantage of the of the economic conditions of the time to effect retrenchments. Lastly, I will also discuss how the South African government responded to the recent global economic meltdown as well as current initiatives aimed at sustaining South African economic growth. South African economy has not been growing at an expected rate since the recession and in 2014 the economic growth also declined due to the strike within the mining sector.

\section{Historical Background of Global Economic Crisis}

Recession or otherwise referred to as the global economic meltdown is generally understood as a period of economic decline; specifically, a decline in gross domestic product (GDP) for two or more consecutive quarters (www.worldcrisis.net). A recession begins when the economy reaches a peak of activity and ends when the economy reaches its trough. Between trough and peak, the economy is in an expansion (2008 www.economist.com). The global economic crisis that resulted from Wall Street Stock market crash on 29 October 1929 has been described as the "Great Depression". The Great Depression was a perfect show of the plunge that a tampered world economy can take, although it originated in the United States, the tremors could be felt across the span of the globe (www.buzzle.com).

Unemployment during the Great Depression worsened with the non-availability of alternate job sources and a total dependency on primary sector industries, which were also hit by associated prices (www.buzzle.com). It has been recorded as the longest, most widespread, and deepest depression of the 20th century. The Great Depression had a pronounced economic and political effect on South Africa, as it did to most nations at the time. As world trade slumped, demand for South African agricultural and mineral exports fell drastically. It is believed that the social discomfort caused 
by the depression was a contributing factor in the 1933 split between the "gesuiwerde" (purified) and "smelter" (fusionist) factions within the National Party and the National Party's subsequent fusion with the South African Party(www.buzzle.com). South Africa was saved from a complete collapse by the gold mining industry, one of the largest and most advanced at the time.

The world was also hit by another economic meltdown in the early 1990s. This recession induced job losses and changes in shares of part-time and fulltime employment significantly varied across demographic groups and gender. American economy also experienced another recession in 2001. Again, between the late 2007 and the early 2008 the world economy experienced yet another economic crisis. As it almost always does, this economic global crisis began in the United States of America (Avgouleas, 2008). The American National Bureau of Economic Research (NBER) announced that there has been a recession since December 2007 in the United States of America, making official what most Americans have already believed about the state of their economy (money.cnn.com). While it was too early in 2008 to decide whether the global financial crisis had already reached its climax, it was however, certain that it will have a devastating effect on the global economy at least throughout 2009. The exposure of the South African economy into the global markets has meant that South Africa was one of the first African countries to be struck by the global financial hurricane. In May 2009, South Africa was reported as officially experiencing recession (Shelton, 2008).

\section{The Impact of Recession on the Labour Market}

\subsection{Global Impact}

There is consensus that the global economic crisis was sparked by a failure of responsible lending practices and investment decisions as well as lack of adequate governance and sufficient regulation. The depth, scope and duration the economic crisis remained difficult to predict and its impact varied from one country to the other, their geographic region and their respective labour market sectors. In nearly all the countries of the world, job losses were mounting; job creation slowed down, unemployment and working poverty increased often dramatically.

The global economic and financial crisis had grown far larger than first anticipated and the world of work was threatened to an unprecedented level. Workers were and still are paying the heaviest cost for a crisis far beyond their control. The impact of the crisis went further than job and income losses, causing the incidence of informal work and working poverty to rise. Young people, migrant and women workers were the most vulnerable to the economic downturn and were all faced with considerable difficulties in integrating in the labour market.

Job losses continue to occur, especially in employment sectors sensitive to economic cycles such as construction and manufacturing, as well as financial services and other sectors. Globally, migrant workers have been among those severely hit by the global economic meltdown. There have been reports of an increase in the return of unemployed migrants to countries of their origin where they are also likely to face inferior economic conditions. Reports from some countries illustrate that reduction in wages, non-payment, availability of few working days, opportunities of overtime, and poor conditions in the workplace are more likely to affect migrant workers who are in the weakest bargaining positions.

Initially, many indicators suggested that the economic crisis will be much deeper and broader, and will last much longer than initially thought. The economic crisis has affected developing countries surprisingly quickly and strongly, through multiple channels: reduced trade flows, decline in commodity prices, reduced liquidity and tightening of credit markets affecting the private and public sectors, reduced flows of remittances, a drop in Foreign Direct Investment (FDI), exchange rate depreciation and uncertainty, and declining flows of Official Development Assistance (ODA) (Owuye dspace.cigilibrary.org) .

\subsection{International Labour Organisation}

The International Labour Office (ILO) issued its annual Global Employment Trends report (GET) assessing the impact of the global financial crisis on employment, unemployment, working poverty and labour market vulnerability in 2009 (.www.ilo.org). According to the this report, the global unemployment is massively on the rise and the worldwide unemployment could increase by as much as 50 million in 2009, adding to the 11 million workers who became newly unemployed in 2008. The economic crisis of 2008 has deepened the concern over the social impacts of globalization which the ILO had previously raised, stressing the need to take measures to support vulnerable groups in the labour market, such as youth and women. The ILO report observes that a huge labour potential remains untapped worldwide and that economic growth and development could be much higher if people are given the chance of a decent job through productive investment and active labour market policies (www2.ilo.org). 
The International Labour Organization has released a new report titled "World of Work Report 2010 - from one crisis to the next?" This report acknowledges that three years into the crisis, the global economy has resumed growing, with some countries witnessing encouraging signs of employment recovery - significantly in emerging economies in Asia and Latin America (www.finchannel.com). Moreover, while some economies are now growing fast, others continue to struggle and some face the prospect of a double dip. Signs of economic recovery started to materialize already in the second half of 2009 but the labour market continued to struggle. This report among other made the following findings (www.finchannel.com):

- The current economic recovery is not creating enough jobs and there are concerns about the quality of the jobs being created. Workers are becoming discouraged and leaving the labour market altogether, which could have long-lasting and devastating effects, especially for young men and women.

- Over the medium term, in advanced economies job growth is expected to remain stagnant through 2010 and a return to pre-crisis levels is not foreseeable before 2015. Estimates suggest that almost 15 million jobs in 35 countries will need to be created in 2011 in order to restore the pre-crisis employment rate

- The policy challenge is to build and ensure a sustainable and inclusive recovery.

Furthermore, the report states that:

\begin{abstract}
a jobless recovery is likely to bring forth a number of social challenges. In particular, as workers become increasingly discouraged by their job prospects, their discontentment could spread and deepen, damaging social cohesion. In addition, as the economic recovery begins to take shape, the social climate may be influenced by the breadth and quality of the jobs recovery. This is of particular concern given that even before the crisis the benefits of the extended growth period were unevenly distributed, i.e. employment growth was in many cases poor in quantity and quality, especially in many developing countries, and income inequality rose in most countries (ILO, 2008b). Decent work is central to people's well-being, and the global social climate is shaped by employment as it provides, among other things, income while paving the way for broader social and economic development (www.finchannel.com: 90)
\end{abstract}

The ILO has reported that economic crisis policies adopted by G20 governments saved or created an estimated 21 million jobs in 2009 and 2010 (www.ilo.org). The ILO study found that the slack in the labour market that accumulated from the second half of 2008 remains high in the first quarter of 2010 despite the beginnings of economic recovery. An additional factor is rising informal employment and poverty in some developing and emerging economies and generally weak growth in real wages in countries at all income levels.

The International Labour Organization has also developed a 'Decent Work' response to the economic global crisis - a Global Jobs Pact. The idea of a Global Jobs Pact is envisaged as a policy contribution by the ILO's tripartite constituency - actors in the real economy - to mitigate the impact of the crisis and to shape a productive and sustainable recovery (Somavia, 2009). In essence, the Global Jobs Pact proposes a balanced and realistic set of policy measure that countries can adopt to strengthen their ongoing efforts to address the crisis. It represents an integrated portfolio of policies that place employment and social protection at the centre of crisis response where the policies can be tailored to national and local situations (Working Paper No. 2, 2010). The ILO has pledged to deepen its collaboration with all relevant partner agencies as called for by the G20 in their London Leaders' Statement.

\title{
3.3 South African Impact
}

As a result of recession, the South African labour market experienced a fall in production which resulted in reduced demand for labour. The Finance and Human Resources industries as well as Trade related sectors, such as the FMCG, Retail \& Wholesale, Mining, Motor, Manufacturing and Distribution, Warehousing \& Freight sectors have been highly affected by recession. Most companies felt the pressures of recession and experienced major financial problems and they effectively effected retrenchments. Some companies felt that it is no longer possible to finance operations that currently contribute to losses and they effected retrenchments. This resulted in labour unrest hence unannounced strikes took place thereby further lowering production volumes in South Africa.

The pace of retrenchments doubled in 2009. It is estimated that a total number of 4899 firms retrenched employees from January 2008 to January 2009 in South Africa. The recession claimed 253000 jobs in the first six months of the year, wiping out more than half of the jobs created since June 2006. According to Statistics South Africa (Stats SA) Quarterly Employment Statistics (QES), 67000 jobs were lost in the second quarter of 2009 in the formal nonagricultural sector relative to the previous quarter, following a revised loss of 186000 (previously 179000 ) jobs in the first quarter of 2009. South Africa's economy lost 198000 jobs year-on-year in the second quarter, which reflects a labour market bleeding from the effects of the recession. Those who are now out of work have limited prospects of finding 
alternative jobs as most sectors have shrunk, with the exception of the government, which in the first half employed a net 23000 more people.

\section{Legal Framework}

In terms of Section 23(1) of the Constitution of the Republic of South Africa, Act 108 of 1996 (hereinafter referred to as the 1996 Constitution), 'everyone has a right to fair labour practice'. This entails that both the employer and the employee have the right to fair labour practices. Section 23 of the 1996 Constitution is given effect to by the Labour Relations Act 66 of 1995 (LRA). In the context of retrenchments, section 185 of the LRA affords an employee the right not to be unfairly dismissed (See NUMSA \& Others v SA Five Engineering \& others 2005 (1) BLLR 53 (LC) and RAWUSA v Schuurman Metal Pressing (Pty) Ltd 2005 (1) BLLR 78 (LC)). On the other hand, sections 189 and 189A provide the employer with the right to dismiss an employee for a fair reason based on the employer's operational requirements and in accordance with a fair procedure.

In terms of section 189A (19) of the LRA, an employee will be found to have been dismissed for a fair reason if "the dismissal was to give effect to a requirement based on the employer's economic, technological, structural or similar needs; the dismissal was operationally justifiable on rational grounds; there was a proper consideration of alternatives; and selection criteria were fair and objective". It is trite law that in terms of section 192(2) of the LRA, the onus of proving that these requirements have been met will lie with the employer. In FAWU obo Kapesi and Others v Premier Foods Ltd t/a Ribbon Salt River (C640/07) [2010] ZALC 61 the court held that 'the LRA does not, however, provide for a definition of the terms "economic", "technological" or "structural". The Code of Good Practice: Dismissal Based on Operational Requirements (the "Operational Requirements Code") defines economic reasons as "those that relate to the financial management of the enterprise" and structural reasons as those that "relate to the redundancy of posts consequent to a restructuring of the employer's enterprise"...'.(para 52).

In SA Commercial Catering and Allied Workers Union and others v Pep Stores (1998) ILJ 1226 (LC), the Labour Appeal Court 'accepted as a valid operational requirement warranting retrenchment the fact that a retail store was suffering massive stock losses due to pilferage and that the employees appeared unable to protect the goods in their custody. In this case the employer notified the union and employees that two of its branches would be closed for an indefinite period during which the employees would receive their full pay. It was common cause that the reason for the closures was the severe stock losses the company was suffering at these branches. The Court accepted that the company had shown good cause to shut down the two branches because they were not profitable and that the reason for that were the unexplained stock losses (shrinkage). The Court accepted that that was a sufficient reason to close the branches for operational requirements' (See also Tiger Food Brands Ltd t/a Albany Bakeries v Levy NO \& others (2007) 28 IU 1827 (LC) 271).

It is generally believed that the word "retrenchments" refer to dismissals of employees for reasons far beyond those employees' control, meaning that such employees are not at fault (Grogan, 2007: 429). These dismissals are justified as being dismissals for operational reasons. Section 189 of the LRA provides guidance on how employers can dismiss employees for reasons based on the employer's operational requirements. In terms of Section 189 (1) of the LRA, the first thing that the employer must do is to consult those affected by a collective agreement, workplace forum or registered trade unions, if there are no such, then the employee(s) concerned must be consulted. Section 189 of the LRA places a duty on the employer to consult when retrenchments are contemplated. In Atlantis Diesel Engines (Pty) Ltd v National Union of Metalworkers of South Africa1995 (3) SA 22, the court held that:

Consultation provides an opportunity, inter alia, to explain the reasons for the proposed retrenchment, to hear representations on possible ways and means of avoiding retrenchment (or softening its effect) and to discuss and consider alternative measures. ... Consultation provides employees or their union(s) with a fair opportunity to make meaningful and effective proposals relating to the need for retrenchment or, if such need is accepted, the extent and implementation of the retrenchment process. It satisfies principle because it gives effect to the desire of employees who may be affected to be heard, and helps serve the underlying policy of the Act, to avoid or at least minimize industrial conflict. Where retrenchment looms employees face the daunting prospect of losing their employment through no fault of their own. Proper consultation minimises resentment and promotes greater harmony in the workplace. (28G - 29C)

The main purpose of consultation between the employer and employees or their representatives is to engage meaningfully in a joint consensus seeking process. Such a process is intended at coming up with appropriate measures to; avoid dismissals, minimise the number of dismissals, change the timing of dismissals and most importantly to mitigate the adverse effects of the dismissals (See section 189 (2) of the LRA). The consultation process ensures that employees 
are provided a platform to forward suggestions on how their jobs can be saved. Such a course would best serve the objectives of the Act and be conducive to industrial peace (see Atlantis Diesel Engines Case at $28 \mathrm{G}-29 \mathrm{C}$ ). This initiative is in line with the right to fair labour practices. In SACTWU v Discreto [1998] 12 BLLR 228 (LAC) 10 it was held that:

\begin{abstract}
Every person has a right to fair labour practices (s. 27 of the Interim Constitution and s. 23 of the 1996 Constitution). As far as retrenchment is concerned, fairness to the employer is expressed by the recognition of the employer's ultimate competence to make a final decision on whether to retrench or not (cf. the Atlantis Diesel case at 1252H (ILJ); $28 \mathrm{I}(\mathrm{SA})$ )). For the employee fairness is found in the requirement of consultation prior to a final decision on retrenchment. This requirement is essentially a formal or procedural one, but, as is the case in most requirements of this nature, it has a substantive purpose. That purpose is to ensure that the ultimate decision on retrenchment is properly and genuinely justifiable by operational requirements or, put another way, by a commercial or business rationale. The function of a court in scrutinising the consultation process is not to second guess the commercial or business efficacy of the employer's ultimate decision (an issue on which it is, generally, not qualified to pronounce upon), but to pass judgment on whether the ultimate decision arrived at was genuine and not merely a sham (the kind of issue which courts are called upon to do, in different settings, every day). The manner in which the court adjudges the latter issue is to enquire whether the legal requirements for a proper consultation process has been followed and, if so, whether the ultimate decision arrived at by the employer is operationally and commercially justifiable on rational grounds, having regard to what emerged from the consultation process. It is important to note that when determining the rationality of the employer's ultimate decision on retrenchment, it is not the court's function to decide whether it was the best decision under the circumstances, but only whether it was a rational commercial or operational decision, properly taking into account what emerged during the consultation process.
\end{abstract}

Section 189(2)(b) of the LRA requires the parties to consult and attempt to reach consensus on the method for selecting the employees to be dismissed. Section 189(7) requires the employer to select the employees to be retrenched according to selection criteria that have been agreed to by the consulting parties; or if no criteria have been agreed, criteria that are fair and objective. Employers do have a right to effect retrenchments, especially if such retrenchments are necessary to sustain the corporation (Tetley $v$ Caterplus (Pty) Ltd (JS286/09) [2010] ZALC 166 para 18). However, in terms of section 23 of the LRA the reasons for such retrenchment should be based on the economic, technological, structural or similar needs of the employer. Typically, economic reasons given for the need for the retrenchment include the ability to make money or to retain sufficient funds to continue operations. Surely employers are entitled to make profits from their businesses and if and when employees they employed no longer help the corporation to make profit, the employer can lawfully dismiss them.

The reasons for retrenchments need not be confined to the current financial situation but could include projected financial circumstances. Technological reasons advanced for the need to retrench often include the introduction of new chemical formulas, equipment, computer packages, electronic systems and techniques that might reduce the need for labour. Structural reasons advanced include "flattening" management structure or switching to a project-based structure. It is refreshing and satisfying that the labour court over the last few years has found that; retrenchment has a "deleterious impact on the life of workers and their families " and can be seen as a "death penalty ". Further that an employer contemplating retrenchments must be able to prove that dismissals of this type were being implemented as "a last resort ". Also that if there was a viable alternative to retrenchments the employer is obliged to implement it (See FAWU \& others v SA Breweries Ltd (2004) 25 IU 1979 (LC))

Indeed, recession in South Africa has tempered with the social security of most workers who were left destitute after being retrenched. Most of these workers spent years of services with their respective workplaces only to be told that due to recession such corporations can no longer afford to retain them. The sad reality is that were employers comply with the statutory requirements relating to retrenchments, during the wave of recession such employers were compelled to effect retrenchments. More so, if the corporation can no longer finance its operations, there is a drop in demand for commodities, production cycles of manufactured products are coming to an end or most importantly such corporation cannot afford to pay employees their salaries, then employers can effect retrenchments (www.solidarityresearch.co.za). However, employers still needed to adhere to the requirements laid down in sections 189 and 189 of the LRA.

When reports that South Africa was officially in recession came forth, various corporations started retrenching their workers and using recession as their excuse. It can be argued that some employers took advantage of the economic conditions of the time, to retrench employees who were not in favour with management without following proper legislative directives. However, the LRA contain comprehensive pre-dismissal procedures which unions can always utilize should they feel like proper procedures were not followed by the employer when effecting retrenchments. Unions can utilize dispute resolution forums or go on strike to challenge retrenchment. It has been argued however, that 'while South African labour law is generally quite protective of employees, it does not provide employees with the right to strike when it 
comes to the retrenchment of some employees' (Chicktay, 2007).

Sections 189 and 189A of the LRA attach a great deal of importance on the culture of consultation before retrenchments take place. If the employer effects retrenchments before he consults with employees or their representatives, it is common cause that such retrenchments will be unfair and employees so retrenched may be reinstated or compensated. Indeed employers are allowed to retrench employees but the process must be fair and must follow proper legislative guidelines, such retrenchments need not be made arbitrarily. Such a decision must be a legitimate business decision and not to get rid of employees who are not in favour with management of the workforce. Furthermore, such a decision must be a genuine commercial decision and not merely a sham.

South Africa is a society strongly committed to the ideal of democracy, including industrial democracy, with an economy increasingly exposed to the disciplining effects of international product, capital and, indeed, labour markets (www.polity.org.za). While the increasingly globalised economy demands high levels of adaptability or flexibility on the part of the labour market and its participants, South Africa's commitment to democracy requires that this must be compatible with labour market security, a point stressed in the opening chapter of the ILO Review.

\section{Competing Interests}

Business community and labour have contrasting interests and the state has a role to harmonize relations between the two. On the one hand, the business community as representing the employers, are aiming at being competitive and maximizing their profits. On the other hand, labour as representing employees, it is concerned with job security of its members and growing its membership. The relationship between the two is one of power play and bargaining. The state has and will always be met with considerable difficulties when trying to harmonize the relationship between the two. This is evident by the wave of strikes that South Africa experienced since the beginning of the current global economic meltdown. Almost every sector, be it private or public, even soldiers have undertaken industrial action in South Africa. Trade unions complained and demanding better wages and improved working conditions (www.essa.org.za). The state has to work hard together with relevant stakeholders to ensure that the conditions under which employees are working under, meets internationally accepted standards.

In various sectors of the South African labour market and in various workplaces, since the beginning of 2008, South Africa had seen major retrenchments especially in the private sector. It cannot be disputed that most employers were hit hard by the global economic meltdown and at most they were forced to effect retrenchments. On the same token, the perception that some employers used the economic conditions of the time to get rid of unwanted employees cannot be ignored. The Congress of South African Trade Unions (COSATU) has come very strong against employers who intent using the global economic recession to dismiss unwanted employees and most importantly to maximize profits. COSATU stated that:

While it recognized the link between the current scale of the "job loss bloodbath" and the international economic meltdown, COSATU felt some employers were merely trying to maximize profits. But at the same time we are worried, as we state in the resolution that some companies are opportunistically jumping onto the bandwagon. We will have to look very carefully at how we can target those employers that we believe are not just scaling down on employment on the basis of the impact of the international crisis, but do so for the reasons of maximizing their profits (www.ecr.co.za).

However, the South African labour law does provide employees who might feel that retrenchments were effected for reasons other those permitted by the LRA with adequate protection. The labour courts can be approached to make appropriate awards to 'unfairly dismissed' employees. The labour court would be able to enquire whether a commercial rationale for the retrenchment existed at the time the retrenchment. The court is entitled to examine the content of the reasons given by the employer for the retrenchment and the fairness thereof (See BMD Knitting Mills (Pty) Ltd v SACTWU (2001) 22 ILJ 2264 (LAC) 2269J- 2270A).

\section{Government Intervention}

The South African government has admitted that unemployment is one of its major challenges. The deputy minister of transport, Jeremy Cronin stated that 'our unemployment crisis lies at the heart of virtually every other challenge we face poverty, inequality, youth alienation, dysfunctional communities' (www.news24.com). It is true that the unemployment crisis in South Africa is deep and profound, even before our economy moved into recession. The government has made the creation of "decent work" the centerpiece of its strategy to halve unemployment by 2015, and sees the state as the 
chief driver of this ambitious target.

However, shortly after his final budget speech in Parliament, Trevor Manuel sounded a necessary warning: "In a time of crisis, all jobs are hard to come by, and the more adjectives you add the harder they will be" (www.news24.com). The high prices of food increases the pressure already felt by the unemployed and the poor, hence there is a need for rapid job creation and sustainable employment. South African state President Hon. Jacob Zuma when delivering his first state of the nation address, told the South Africans that 'government planned to create 500000 job opportunities by the end of 2009 with another four million jobs by 2014 (www.mg.co.za). It will be interesting how the government will go about turning these opportunities into real and sustainable work. Some of these job opportunities came from the construction sector when South Africa prepared for hosting 2010 FIFA Soccer World Cup.

South Africa is a middle-income, emerging market with an abundant supply of natural resources; well-developed financial, legal, communications, energy, and transport sectors; a stock exchange that is 17th largest in the world; and modern infrastructure supporting an efficient distribution of goods to major urban centres throughout the region (Working Paper No. 2, 2010). South Africa's financial sector has been able to navigate the crisis successfully due to an adequate regulatory framework and well developed risk management systems. However, the collapse of the global demand, significant reduction in consumer and business confidence and the collapse in commodity prices has had an impact on the South African economy.

The South African government responded to the global economic crises by launching a national job initiative which was designed to speed up the financing of job creation and job retention measures (Global Economic Crisis, 2009). In December 2008 the social partners that comprise the Presidential Economic Joint Working Group, namely organised Labour, Business and Government, met to consider how South Africans should respond collectively to the economic difficulties South Africa experienced at the time. As a result of this meeting, the 'Framework for South Africa's Response to the International Economic Crisis' document was produced. This report recognised the need to take steps to avoid placing the burden of the economic downturn on the low income workers, the unemployed and the vulnerable groups (Global Economic Crisis, 2009: 4)) Social partners and government also aimed to ensure that their activities were aimed at strengthening the capacity of the economy to grow and create decent jobs in the future.

The framework document recommended a broad stimulus package that has economic and social components. The proposed package will cater for significant levels of public investment in infrastructure as one of the key means of responding to the downturn in the economy. There was an agreement that a significant part of the national response to the global economic slowdown should be to rebuild local industrial capacity and avoid de-industrialisation during the period ahead. Further that, a special National Jobs Initiative, led by the Presidency that brings together a range of new and revamped separately administered programmes will be launched. The value of the new and revamped schemes is estimated at about R10 billion over the three years Medium Term Expenditure Framework.

It was further agreed that 'there is scope for improving the employment intake by the public sector in the process of strengthening the education, health and social work sectors and criminal-justice system in SA and filling departmental vacancies at national, provincial and municipal levels'. (Global Economic Crisis, 2009: 15). Social partners and government also recognised the need to prioritise training and skills development and also to improve quality as well as enhance learnership programmes. However, the 'Framework for South Africa's Response to the International Economic Crisis' document has been criticised for identifying sector strategies as the only urgent priority and proposing that significant state resources be made available to those sectors, along with accepted measures and appropriate incentives (www.saiia.org.za).

\section{Surviving Recession and Sustaining Economic Growth}

Even though much of the world staggered in the wake of the global financial meltdown, South Africa has managed to survive the meltdown largely due to its prudent fiscal and monetary policies. In the third quarter of 2009, statistics South Africa reported that South Africa has moved out of recession. Further that 'the seasonally adjusted real gross domestic product (GDP) at market prices for the third quarter of 2009 increased by an annualised rate of 0.9 percent compared with the second quarter of 2009' (www.sagoodnews.co.za). The main contributors to the growth in economic activity for the third quarter of 2009 were the manufacturing industry, general government services, construction industry and personal services. The primary importance of high economic growth for South Africa's future, with the emphasis on the correlation between growth and employment to address poverty, is being acknowledged increasingly across ideological boundaries. Although economic growth is not the absolute answer to all South Africa's problems, it is inconceivable that large-scale unemployment can be addressed without a drastic expansion of the economy (Laubscher, 2013). However, South African economic growth has not been stable since the country officially moved out of recession. From 2010 to 
2012, the economy grew at a rate of between 2 to $3.7 \%$ and from 2012 to 2013 the economic growth has been declining from $2.7 \%$ to $1.8 \%$ (www.moneyweb.co.za).

Despite slow economic growth, South Africa has experience a major strike action in the mining sector. Mining and manufacturing account for about a fifth of South Africa's economy, but have been plagued by strikes in the past few years. The current mining strike, over wages which started in January 2014, is the costliest and longest in South Africa's history (City Press, 27 May 2014). It has been reported that South Africa's economy shrank 0.6\% quarter-on-quarter in the first three months of 2014. The contraction - the first in the South African economy since 2009 - is due to a massive decline in output from the strike-hit platinum-mining sector. There are concerns that if this strike continues, South African may get back into recession. Nonetheless, the South African new minister of mineral resources, Mr Ngoako Ramatlhodi has set up a task team to investigate ways of resolving the platinum mining strike (Marus, 2014). The association of Mineworkers and Construction Union has accepted a wage offer by platinum producers, bringing an end to the five-month strike in the platinum sector. It is concerning that the largest trade union in South Africa, the National Union of Metalworkers of South Africa has the National Union of Metalworkers of South Africa has indicated that it will be going on strike in spite of warnings that the industrial action would hurt the economy (Marrian, 2013). If this strike goes ahead, South African economy will be adversely affected.

However, South African former Minister of Finance, Mr Pravin Gordhan has indicated that South African economy is expected to grow by $1.4 \%$ to $3.5 \%$ over the next three years (Chauke, 2013). Gordhan has argued that through collaboration with business, labour and state-owned companies, the government has tackled short and long-term sectoral constraints to deal with economic challenges and bringing about stability. This includes an agreement to rapid and peaceful resolution of labour disputes in the mining sector, the biggest contributor to the Gross Domestic Product. Gordhan said other factors that are expected to boost growth included: Improving the efficiency, pricing capacity of local ports to reduce transport costs and enhance competitiveness; Investing in freight capacity to help alleviate bottlenecks; and Improving access to finance and support services for small businesses (Chauke, 2013).

In order to achieve sustainable growth, the African National Congress adopted the National Development Plan at its latest conference in Magaung. As a result, the South African National Planning Commission was set up to produce a working document with proposals on how to achieve sustainable growth which will go a long way in addressing varied challenges faced by South Africa. In 2011, South African National Planning Commission published the National Development Plan vision 2030. This plan is aimed at strengthening the capability of South Africans through education, skills, decent accommodation, nutrition, safe communities, social security, transport and job opportunities. According to this plan:
Achieving full employment, decent work and sustainable livelihoods is the only way to improve living standards and ensure a dignified existence for all South Africans. Rising employment, productivity and incomes are the surest long term solutions to reducing inequality. Similarly, active steps to broaden opportunity for people will make a significant impact on both the level of inequality and the efficiency of the economy (National Development Plan: vision 2030: 90).

The National Development Commission submits that the capabilities of the workforce need to be developed on a broader scale by creating a stable and constructive environment for bargaining and labour relations that supports investments. This commission further submits that the rate of investment to Gross Domestic Product is expected to rise from $17 \%$ to $30 \%$ by 2030 . National Development Plan: vision 2030:90). This to this plan is the creation of jobs, a large percentage of which it is claimed that they will be created in domestic orientated activities and in the service sector. According to this plan, economic participation in rural areas will rise from $29 \%$ to $40 \%$ as a result of transformed land tenure, support to farmers, expanded social services, higher agricultural output, mining social investment and tourism.

This plan also recognises the impact of the global economic crisis on the South African economy. In order to counter this, this plan among others proposes that: government needs to build in micro-policy cushions to enable South Africa to counteract the effects of the financial crisis; that a balancing act needs to be struck between the need to curb inflation and the need to keep the embers of economic growth alive; that accumulation of foreign reserves remains the best way to manage capital flows and prevent prolonged overvaluation and further that a spike in unemployment must be met with interventions to protect the most vulnerable, particularly the young who cannot find jobs (National Development Plan: vision 2030: 102).

However, this plan has been criticised in various sectors within South Africa. It has been argued that:

In the wake of the financial crisis, and policy shifts around the world the NDP proposes a shockingly orthodox macroeconomic vision. The NDP reveals the old Gear paradigm of macro-economic stability, and fiscal restraint, within liberalised financial markets. The focus on 'spending efficiency' is code for fiscal restraint ; focus on 'investment vs 
consumption' spending is code for reducing spending on salaries and grants etc. there is no talk of a systematic programme of macroeconomic stimulus to respond to current global conditions. In fact it supports the current line in government and the ANC of the need for some monetary policy easing, combined with more fiscal restraint (www.cosatu.org.za).

Mr Kane-Berman, the CEO of the South African Institute of Race Relations has also criticised the National Development Plan, arguing that the NDP is a hotch-potch of contradictory ideas that have not been properly costed and are bound to fail. The lack of future scenarios for tax revenues, budget deficits or the public debt means that an endorsement of the NDP amounts to giving the government "a blank cheque for more taxation and more borrowing and probably for both (Ensor, 2013).

\section{Conclusion}

The global financial crisis put severe pressure on the main sources of external revenues for most countries of the world, especially developing countries. As a result, growth and efforts to reduce poverty have seriously been hampered. This economic crisis led to various corporations around the world to retrench employees. Some of these corporations closed down, whereas others obtained government bail outs. It was shown in this paper that the economic crisis started in the United States of America and spread throughout the world. The South African labour market was also severely affected as many employees lost their jobs. Nonetheless, South Africa's macroeconomic policies have contributed impressively to the country's development. These policies have been underpinned by a consistent and transparent policy framework, including a credible inflation targeting regime. The South African Reserve Bank also aggressively eased monetary policy starting in late 2008. As economic activity weakened and the inflation outlook improved, the monetary policy committee (MPC) reduced interest rates by 450 basis points between December 2008 and May 2009.

Even though South Africa has officially moved away from recession, the country's economic has not been growing at an expected rate making it difficult to create new jobs. Furthermore, even though there are those who do not see the National Development Plan as a solution to the economic challenges South Africa is facing, it seems live government has adopted it and is optimistic that it will go a long way in addressing South African economic challenges. However, the true test of the National Development Plan will be in its implementation. There are indicators pointing towards a turnaround in economic fortunes in South Africa. However, there is still a lack of certainty as to what will drive sustainability of economic growth in South Africa.

\section{References}

\section{Books}

Grogan, J. Dismissal, Discrimination, and Unfair Labour Practices (2007: Juta \& Co)

Moleke, P. "The State of the Labour Market in Contemporary South Africa" in J Daniels, A Habib, \& R Southall (eds) The State of the Nation: South Africa (2003-2004: Cape Town: HSRC Press)

Ritholtz, B. and Aaron Task, A., Bailout Nation: How Easy Greed and Easy Money Corrupted Wall Street and Shook the World Economy (2009: John Wiley \& Sons Inc, Hoboken, New Jersey)

\section{Journal Articles}

Ene, C, (2011) Romanian Vulnerabilities in the Current Financial and Economic Crises Context' (2011) Issue 4, 1.

Employers' Organisations Responding to the impact of the Crisis: Working Paper No. 2 ILO Bureau for Employers' Activities (2010)

\section{Statutes}

Constitution of the Republic of South Africa Act 108 of 1996

Labour Relations Act 66 of 1995

\section{Cases}

BMD Knitting Mills (Pty) Ltd v SACTWU (2001) 22 ILJ 2264 (LAC) 2269J- 2270A

FAWU obo Kapesi and Others v Premier Foods Ltd t/a Ribbon Salt River (C640/07) [2010] ZALC 61

NUMSA \& Others v SA Five Engineering \& others 2005 (1) BLLR 53 (LC) 
SA Commercial Catering and Allied Workers Union and others v Pep Stores (1998) ILJ 1226 (LC)

SACTWU v Discreto [1998] 12 BLLR 228 (LAC) 10

Tetley v Caterplus (Pty) Ltd (JS286/09) [2010] ZALC 166

Tiger Food Brands Ltd t/a Albany Bakeries v Levy NO \& others (2007) 28 IU 1827 (LC) 271.

wezar

\section{Websites}

http//:www.tralac.org

http//:www.businesssculptors.com

http//:www.investorwords.com/4086/recession.html.

http://www.nber.org/cycles/dec2008.html.

http://www.buzzle.com/articles/unemployment-during-the-great-depression.html

http://www.informaworld.com/smpp/content $\sim \mathrm{db}=$ all content=a713758085

http://portal.unesco.org/fr/ev.php-.html

http://www.informaworld.com/smpp/content db=all content=a713758085 (accessed 29 October 2009).

http://money.cnn.com/2008/12/01/news/economy/recession/index.htm

http://www.voxeu.org/index.php?q=node/3362

http://www.ioe-emp.org/fileadmin/user_upload/documents_pdf/globaljobscrisis/ioe_documents/2009

http://www.iom.int/jahia/webdav/site/myjahiasite/shared/shared/mainsite/policy_and_research

http://www.groundreport.com/World/Global-Financial-Crisis-Affects-International-Lab̄o/2874608(accesseD 30 October 2009)

http://www.groundreport.com/World/Global-Financial-Crisis-Affects-International-Labo

http://youth.ituc-csi.org/The-Global-Economic-and-Financial (accessed 30 October 2009)

http://www.iom.int/jahia/webdav/site/myjahiasite/shared/shared/mainsite/policy_and_research

http://portal.unesco.org/fr/ev.php- =201.html

http://www.ilo.org/wcmsp5/groups/public

http://business.iafrica.com/features/1919160.htm

http://www.fin24.com/articles/default/display_article.aspx?

http://www.busrep.co.za/index.php?fArticleld=5175447

www.labour.gov.za/media-desk/speeches/2005/18th-annual-labour-law-conference ( accessed 11 November 2009).

www.polity.org.za/polity/govdocs/commissions/fin1.html

http://www.sagoodnews.co.za/employment/towards_a_more_flexible_labour_market_html

http://www.essa.org.za/download/2007conference/Heintz\&Posel_segmentation.

http://www.ecr.co.za/kagiso/content/en/east-coast-radio-Detail\&pid=5884

http://www.news24.com/printArticle.aspx?iframe\&aid=55a0de90-f9d8-41fc-b5a8-6444377637d2\&cid=984

http://www.mg.co.za/article/2009-07-24-zuma-sa-will-wait-for-jobs-increase

http://www.tradeinvestsa.co.za/feature_articles/364320.htm

http://www.imf.org/external/pubs/ft/survey/so/2009/car092509a.htm

http://www.ihsglobalinsight.co.za/News/news.asp?id=900

http://www.sagoodnews.co.za/economy/sa_moves_out_of_recession.html http://www.travelwires.com/wp/2009/07/2010

http://www.sanews.gov.za/south-africa/economy-expected-grow-gordhan (accessed 4 0ctober 2013) 